\title{
Extensive ameloblastoma in young patient: 5-year follow-up with no recurrence using conservative treatment
}

\author{
Ameloblastoma extenso em paciente jovem: proservação de 5 anos sem recidiva com tratamento \\ conservador
}

Joyce Natiele da SILVA'

(iD) ORCID iD 0000-0002-6486-9819

Cassiano Nogueira dos SANTOS 2

(iD) ORCID iD 0000-0002-0012-3903

André Caroli ROCHA

(iD) ORCID iD 0000-0003-0070-0640

Marina Lara de CARLI ${ }^{1}$

(iD) ORCID iD 0000-0002-1133-6242

João Adolfo Costa HANEMANN ${ }^{1}$

(iD) ORCID iD 0000-0002-3865-905X

Alessandro Antônio Costa PEREIRA ${ }^{1}$

(iD) ORCID iD 0000-0002-2763-8405

\begin{abstract}
Ameloblastoma is a benign, odontogenic tumor that, due to its low rate of incidence, slow growth and local invasiveness, can be treated with a variety of surgical approaches, ranging from conservative to radical procedures. The conventional variant of ameloblastoma, though, is more aggressive and common, presenting a higher rate of recurrence than the unicystic and extraosseous/peripheral types; usually, the treatment of choice for this variant employs more invasive procedures. This report is of a 13-year-old male patient who presented with a swelling on the posterior mandibular region, on the left side of his face. Intraoral examination revealed lingual displacement of teeth 36 and 37. The clinical, radiographic and histopathological analyses confirmed the diagnosis of ameloblastoma (plexiform histological type). The patient was treated with curettage and peripheral osteotomy and a 5-year follow-up examination showed the area to have healed completely, with no evidence of recurrence. Consequently, although the clinical management of ameloblastoma is often based on invasive surgical approaches, large tumors treated with conservative surgery are less aesthetically and functionally impaired, and may demonstrate good prognosis with no recurrence in the 5-year follow-up period, as in the case reported here.
\end{abstract}

Indexing terms: Ameloblastoma. Recurrence. Therapy.

\section{RESUMO}

O ameloblastoma é um tumor odontogênico benigno que pode ser tratado com diferentes abordagens cirúrgicas, variando desde procedimentos conservadores a radicais, devido à sua baixa frequência, crescimento lento e capacidade localmente invasiva. A variante convencional deste tumor é mais agressiva e frequente com uma maior taxa de recorrência comparado aos tipos unicísticos e extraósseo/periférico. Um paciente do gênero masculino, 13 anos de idade, apresentou-se com a queixa de uma tumefação na região mandibular posterior no lado esquerdo da face. Ao exame físico intrabucal, observou-se o deslocamento dos dentes 36 e 37 para lingual. A avaliação clínica, imaginológica e histopatológica confirmaram o diagnóstico de ameloblastoma do tipo histológico plexiforme. O paciente foi tratado com curetagem e osteotomia periférica. A proservação de 5 anos mostrou uma completa cicatrização da área sem sinais de recidiva da lesão. O manejo do ameloblastoma permanece baseado na abordagem cirúrgica radical, no entanto, tumores extensos tratados com cirurgia conservadora apresentam menor comprometimento da estética e função, e podem demonstrar um bom prognóstico sem recorrências em 5 anos de proservação, semelhante ao presente caso relatado.

Termos de indexação: Ameloblastoma. Recidiva. Terapia.

\section{INTRODUCTION}

Ameloblastoma is a slow-growing, locally invasive, benign epithelial odontogenic tumor (EOT). Its pathogenesis has not been determined and originates from the epithelial remains of the dental lamina, the enamel organ, basal cells of the oral mucosa or the epithelial lining of an odontogenic cyst $[1,2]$.

\footnotetext{
${ }^{1}$ Universidade Federal de Alfenas, Faculdade de Odontologia. Rua Gabriel Monteiro Silva, 700, Alfenas, MG, Brasil. Correspondência para / Correspondence to: JN SILVA. E-mail: <joycenatieledasilva@yahoo.com.br>.

${ }^{2}$ Consultório particular. Itanhandu, MG, Brasil.

${ }^{3}$ Consultório particular. São Paulo, SP, Brasil.

$\checkmark v$ vor

Como citar este artigo / How to cite this article

Silva JN, Santos CN, Rocha AC, Carli ML, Hanemann JAC, Pereira AAC. Extensive ameloblastoma in young patient: 5-year follow-up with no recurrence using conservative treatment. RGO, Rev Gaúch Odontol. 2018;66(2):00-00. http://dx.doi.org/10.1590/1981-8637201800020000133357
} 
Ameloblastomas occur at any age, the literature [2-4] reporting that the majority of cases are diagnosed in individuals aged between 30 and 60, and approximately $80 \%$ of cases occur in the mandible [1,4-6], predominantly in the region of the molars and ramus 7,8 and have a high rate of recurrence [5-8].

According to the latest edition of the book on Head and Neck Tumors published by the World Health Organization (WHO) [9] at the beginning of 2017, ameloblastoma can be classified as: ameloblastoma, unicystic ameloblastoma or extraosseous/peripheral ameloblastoma, with the terminology solid or multicystic, used since the last WHO classification in 2005, being discarded as it has no biological meaning, while the term desmoplastic will no longer be used as a clinicalpathological entity but rather as a histological subtype. Ameloblastoma is regarded as the variant with the highest rate of recurrence, more aggressive [10] and more common than the unicystic or extraosseous form $[11,12]$. The final diagnosis is performed via a microscopic examination, however clinical examinations, and imaging examinations using radiography and computed tomography, help to provide a differential diagnosis [13].

With regard to the treatment of ameloblastoma, options include conservative forms such as marsupialization [14], curettage, enucleation and cryotherapy, while the more radical forms include marginal resection or segmental block-excision $[1,4]$ and treatment of the operative field with chemical (Carnoy's solution), physical (ostectomy) or thermal (cryotherapy) substances $[6,10]$. The chosen mode of therapy will depend on the characteristics of the lesion, where, in more minor lesions, in the initial stages, with little destruction of the bone, it would be possible to carry out the treatment by preserving bone continuity, although chemical or cryotherapeutic treatment of the operative field is recommended $[6,15]$. Bone reconstructions can be done with free bone grafts, the anterior iliac being the donor area most used. For more extensive wounds, the fibula can be used as the option for vascularized bone grafts [14].

The proposal of the present study is to present and discuss conservative treatment of an extensive ameloblastoma in a teenage patient, emphasizing the relevant circumstances of the surgical approach employed relating to curettage and peripheral osteotomy. A 5-year clinical and radiographic follow-up is presented, there being no evidence of reversion up to the present time.

\section{CLINICAL CASE}

Y.R.M., a thirteen-year-old Caucasian male patient, approached the diagnostic services department at the Federal University of Alfenas (UNIFAL), in 2006, recounting that he had observed a non-painful, volumetric increase in the mandible five months previously, with a progressive increase in size, but which only hurt when chewing. During anamnesis, no systemic changes were found. Upon extraoral physical examination, we noted a slight limitation in oral aperture, a diffuse tumefaction in the region of the left-side mandibular body and angle, causing asymmetry of the face (Figure 1). The submandibular lymph node on the left side was infarcted and painful on palpation, while the remaining lymph nodes were normal. The buccal cortex on the left side presented with crepitus and pain on palpation. The intraoral examination revealed tumefaction in the leftside posterior region of the mandible, causing lingual displacement of teeth 36 and 37, with excessive mobility in tooth 37 and slight mobility in 36 (Figure 2).

The radiographic examination revealed an extensive multilocular radiolucent lesion in the left-side posterior mandibular region, with root resorption of teeth 36 and 37 and displacement of the germ of tooth 38 to the base of the mandible, close to the angle. The lesion extended to the premolar region (Figure 3).

The diagnostic hypotheses were keratocystic odontogenic tumor, ameloblastoma and central giant cell lesion. Upon puncture aspiration, a liquid was obtained with a bloody appearance and, as a consequence, an incisional biopsy was performed.

The characteristics under microscope revealed that it was an ameloblastoma of the plexiform histological type (Figure 4).

The surgical treatment employed was curettage and peripheral osteotomy, and also extraction of teeth 36 , 37 and 38 (Figure 5).

Being an aggressive tumor with a high rate of recurrence, the patient was monitored using clinical and radiographic checks of the lesion. After five years of follow-up, no recurrence was reported (Figure 6). 


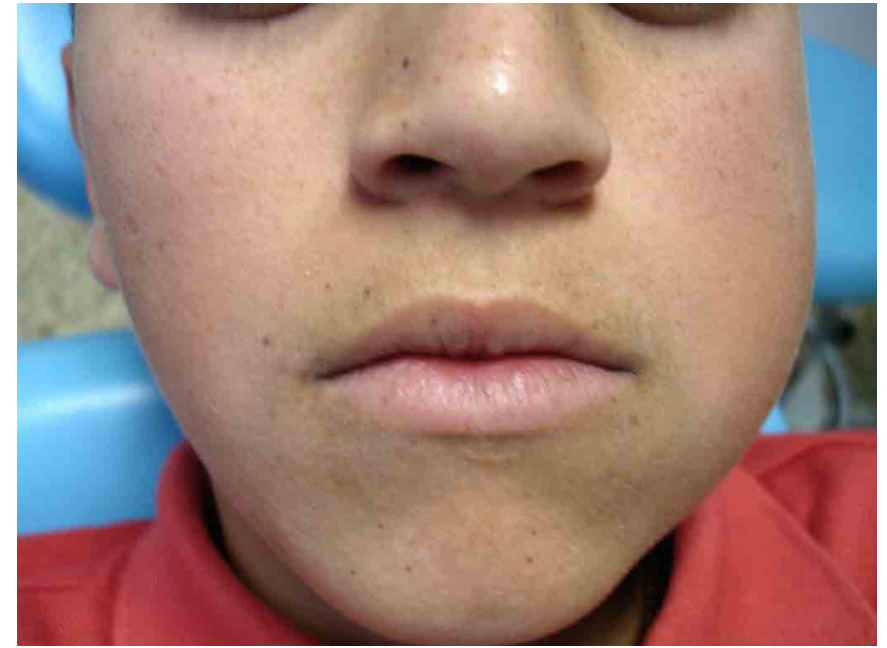

Figure 1. 13-year-old male patient with diffuse tumefaction in the left-side region of the mandibular body and angle, causing asymmetry of the face, nonpainful and firm on palpation.

Place and year of the study: UNIFAL, Alfenas, in 2006.

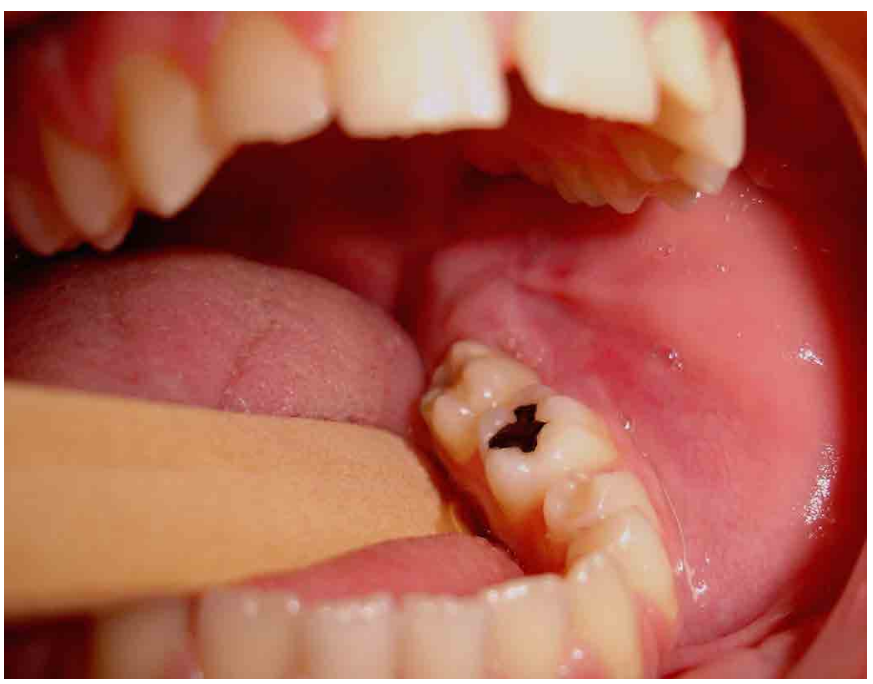

Figure 2. Intraoral examination evidencing tumefaction with normal surface in the left-side posterior region of the mandible and lingual displacement of teeth 36 and 37. Non-painful and firm on palpation.

Place and year of the study: UNIFAL, Alfenas, in 2006.

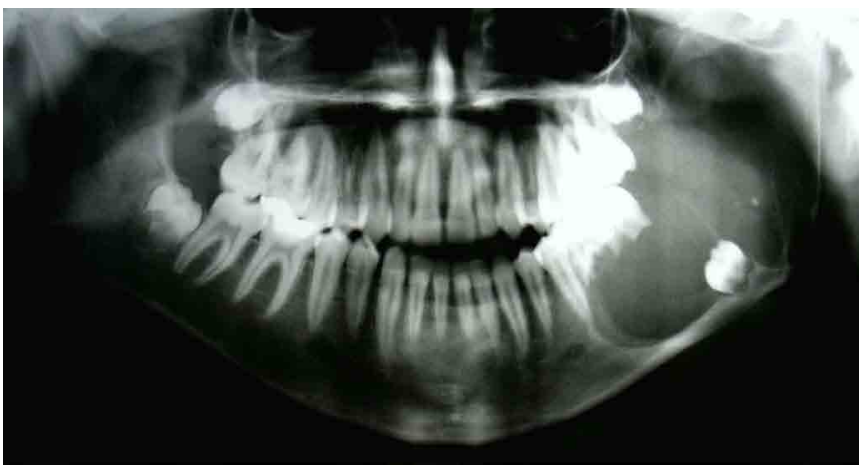

Figure 3. Panoramic radiograph evidencing extensive multilocular radiolucent lesion in the left side of the mandible, with root resorption of teeth 36 and 37 and displacement of the germ of tooth 38 towards the base of the mandible, close to the angle. Limits defined in the premolar region.
Place and year of the study: UNIFAL, Alfenas, in 2006.

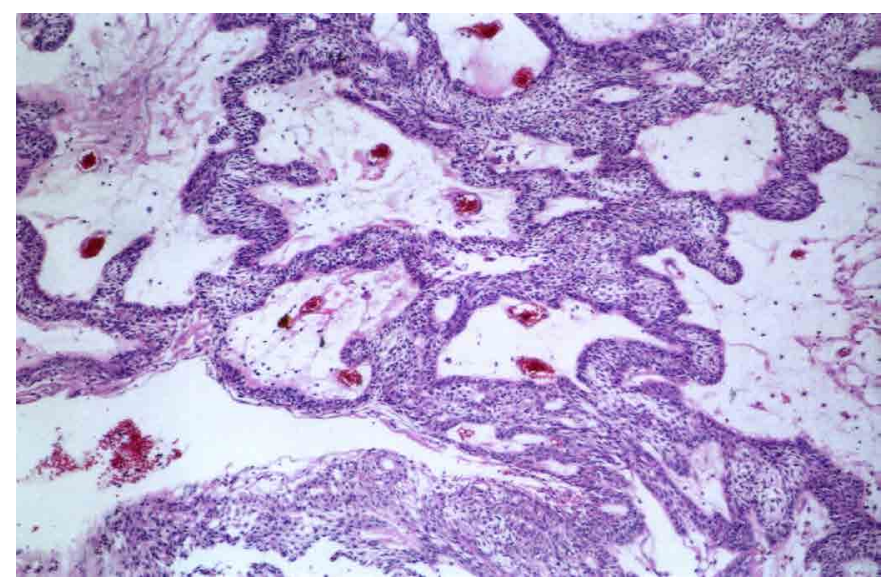

Figure 4. Histological view of the plexiform pattern presenting long, connecting strings of odontogenic epithelium with the presence of moderately vascularized and loosely arranged stroma.

Place and year of the study: UNIFAL, Alfenas, in 2006.

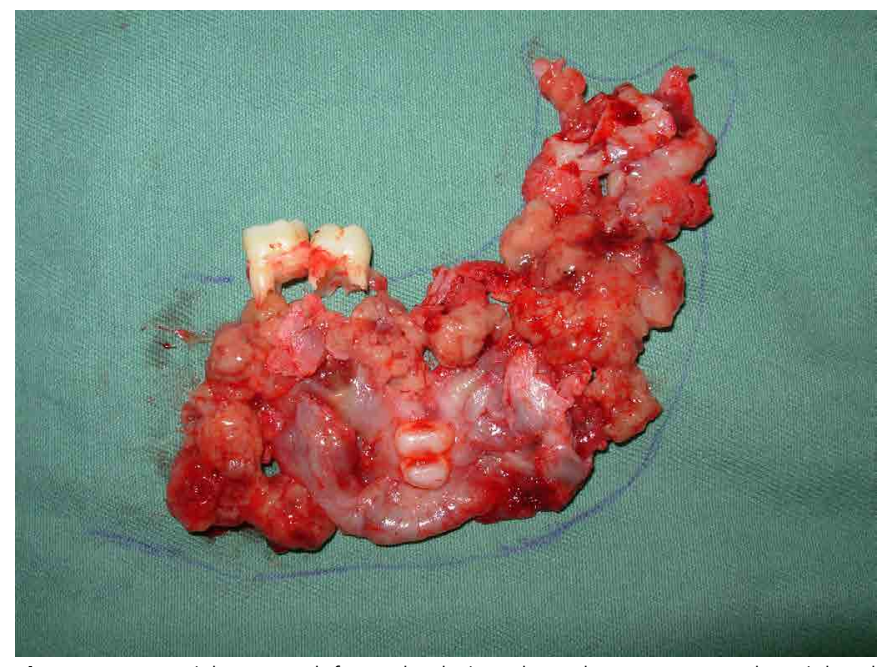

Figure 5. Material removed from the lesion through curettage and periphera osteotomy. Teeth 36,37 and the germ of tooth 38 were extracted.

Place and year of the study: UNIFAL, Alfenas, in 2006.

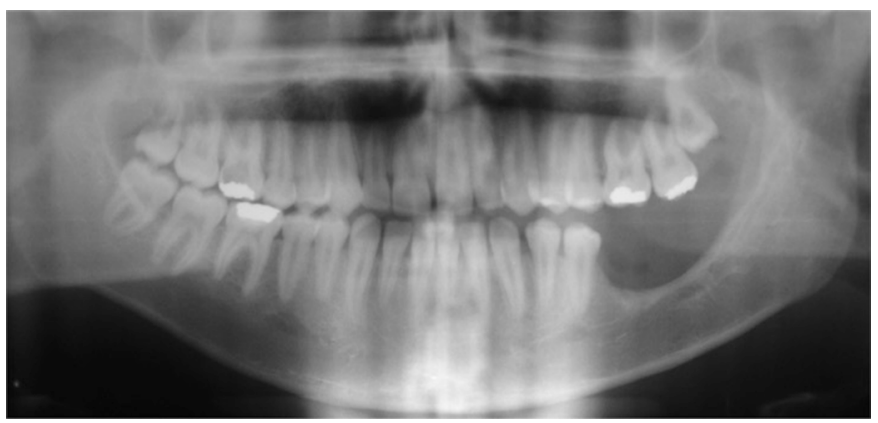

Figure 6. Five-year radiographic check showing no recurrence. 
Place and year of the study: UNIFAL, Alfenas, in 2011.

\section{DISCUSSION}

Ameloblastoma in young patients is not considered very frequent, equating to approximately $10 \%$ to $15 \%$ of all reported cases of this tumor and it is rare for it to develop in children [4]. The unicystic form is the one most commonly found in individuals under 20 years of age $[4,14]$. This article presents a case of ameloblastoma in an unusual age group, the patient being thirteen years old.

Radiographically, ameloblastoma may manifest itself as a well-defined unilocular radiotransparency with or without the presence of sclerotic margins, frequently associated with an unerupted tooth, or as multilocular radiotransparency, that may be described in terms of the phrases "honeycombs" or "soap bubbles". Ameloblastomas can be extensive, to the point of perforating the bony cortex, invading the soft tissue, or resorbing and/ or displacing teeth $[1,13,16]$. In the present clinical case, the radiograph revealed a multilocular appearance, with root resorption of teeth 36 and 37 and displacement of tooth 38, with no report of any paresthesia in the region, which can occur in advanced cases of ameloblastoma [17]. As far as location is concerned, $80 \%$ of ameloblastomas are found in the posterior region of the mandible and are frequently associated with unerupted teeth ${ }^{4}$. In the case described here, the neoplasm was located in the mandibular body and angle, involving tooth 38 which was in the process of incomplete rhizogenesis. The type of microscopic pattern found in the present clinical case was plexiform, in agreement with the authors Fregnani et al. [18] and Alvarenga et al. [1] who ascertained that the plexiform pattern is the type most commonly found, at around $53 \%$ and $41.7 \%$ of cases, respectively.

Ameloblastoma possesses variable radiographic characteristics and should, therefore, always be considered with diagnostic suspicion in cases similar to the lesion presented here [4]. The diagnostic hypotheses in this case were keratocystic odontogenic tumor, ameloblastoma and central giant cell lesion, evidencing that, from the outset, the suggestion of ameloblastoma was quoted, demonstrating how important it is for the dental surgeon to have a good knowledge of the literature, as the hypothesis of greater aggressiveness was in fact the final diagnosis.

The choice of surgical method may be influenced by the patient's age and systemic condition, neoplasm histology, extent and location of the lesion, imaging characteristics, if the pathology is primary or recurrent, the professional's experience, clarification about the risks and benefits of each therapy proposed to the patient and family members, and the possibility of post-treatment follow-up $[1,14,16,19]$.

Of the various forms of treatment, i.e. curettage, marsupialization, enucleation, cryotherapy, Carnoy's solution, surgical resection, among others $[1,4,14,20]$, the option of curettage and peripheral osteotomy was decided upon. In the literature review conducted by Rezende et al. [20] curettage, in other words the removal of the tumor performed by excavating around the normal bone, does not produce satisfactory results and has high rates of recurrence. The treatment of choice for ameloblastomas is usually radical surgery, however, if the possibility of a suitable solution to the lesion exists with reduced sequelae, conservative treatment may be performed $[6,15,20,21]$. For ameloblastoma, a wide local excision with margins of between 1.5 and $2 \mathrm{~cm}$ is recommended [22]. Even in the knowledge that this neoplasm has a higher rate of recurrence, with as much as a $90 \%$ chance after conservative treatment [10], the more conservative treatment was the option taken, mainly due to the patient's age (13 years), in which a more radical surgery could result in greater disruption in terms of facial growth and quality of life, influencing appearance, chewing and speaking. A study carried out by Lawal et al. [23] aiming to analyze the quality of life of patients treated surgically for ameloblastoma, found that the patients quality of life reduces immediately after surgery, but gradually improves over time, and that, with regard to location, tumors in the posterior region showed better results with regard to postoperative quality of life [23]. In the present case, it was decided to perform the surgical technique involving curettage and peripheral osteotomy which, despite it involving less disfigurement, requires a longer postoperative follow-up due to the increased possibility of reversion. According to Paiva et al. [6], the first intervention is the most important in view of the fact that, in the event of a recurrence, the anatomical references are lost and may therefore increase contamination of areas adjacent to the lesion and the chance of new local tumors.

In the study conducted by Milman et al. [10], the authors observed recurrence in $24 \%$ of patients with ameloblastoma, the average period of time to the first relapse being 4.6 years. The present case report differs in that there was no relapse within the follow-up period 
of 5 years. However, Siar et al. [24] found recurrence in $13.3 \%$ of cases in an average period of 7.3 years. The authors Hertog et al. [25], in an examination of 35 cases of ameloblastoma between 1970 and 2010, found 28 cases that had been treated using enucleation, of which $60 \%$ suffered one or more recurrences during an average follow-up period of 8.3 years. In 8 of the 11 patients aged under $20(73 \%)$, recurrence was observed. Moreover, the authors Milman et al. [10] ascertained that the type of surgery was linked to recurrence, particularly those treated with limited surgery (marginal excision, enucleation and curettage). The present case reports the possibility of nonrecurrence of ameloblastomas with conservative treatment of curettage and peripheral osteotomy. This suggests that a detailed clinical and imaging evaluation of ameloblastomas afflicting the mandible, as well as preplanned surgical treatment, albeit conservative, evaluating the margins of the lesion, might offer a life free from recurrences. Postoperative follow-up is important for the treatment and prognosis as over $50 \%$ of all recurrences occur within the

\section{REFERENCES}

1. Alvarenga RL, Jaeger F, Nascimento JHG, Leal RM. Ameloblastoma: un estudio retrospectivo de 48 casos. Rev Esp Cir Oral Maxilofac. 2013;35(4):145-9. doi: 10.1016/j.maxilo.2013.03.001

2. Scherma AP, Monteiro RM, Oliveira RV. Ameloblastoma em crianças e adolescentes: revisão da literatura. ClipeOdontoUNITAU. 2013:5(1):51-7.

3. Adebayo ET, Fomete B, Adekeye EO. Delayed soft tissue recurrence after treatment of ameloblastoma in a black African: case report and review of the literature. J Craniomaxillofac Surg 2011;39(8):615-8. doi: 10.1016/j.jcms.2010.05.010

4. Muniz VRVM, de Freitas DJSM, Neri RFA, Dultra JA, Dultra FKAA. Características clínicas, radiográficas e diagnóstico do ameloblastoma: relato de caso. Rev Cir Traumatol Buco-MaxiloFac. 2014;14(4):27-32

5. Gunawardhana KSD, Jayasooriya PR, Rambukewela IK, Tilakaratne WM. A clinico-pathological comparison between mandibular and maxillary ameloblastomas in Sri Lanka. J Oral Pathol Med. 2010;39(3):236-41. doi: 10.1111/j.1600$0714.2009 .00850 \cdot x$

6. Paiva LCA, Santos MESM, Silva DN, Heitz C, Filho MS. Potencial de recidiva do ameloblastoma: relato de caso. Rev Cir Traumatol Buco-Maxilo-Fac. 2010;10(1):27-34.

7. Kim JD, Jang HS, Seo YS, Kim JS. A repeatedly recurrent desmoplastic ameloblastoma after removal and allobone graft: Radiographic features compared with histological changes. Imaging Sci Dent. 2013;43(3):201-7. doi: 10.5624/ isd.2013.43.3.201 first 5 years of the follow-up phase [2].

\section{CONCLUSION}

In the present report, the 5-year follow-up period already suggests the treatment was successful, but we acknowledge that the benefits of follow-up after surgical treatment should be emphasized to the patient, as recurrences may occur even after a long period of time. It is vital that the patient's clinical and radiographic follow-up be maintained.

\section{Collaborators}

JN SILVA, drafting the manuscript and clinical diagnosis. CN SANTOS, clinical diagnosis. AC ROCHA, performed the incisional biopsy and surgical treatment. ML CARLI, clinical diagnosis, JAC HANEMANN, performed the incisional biopsy and surgical treatment. AAC PEREIRA, performed microscopic diagnosis.

8. Bataineh A. Effect of preservation of the inferior and posterior borders on recurrence of ameloblatomas of the mandible. Oral Surg Oral Med Oral Pathol Oral Radiol Endod. 2000;90(2):15563. doi: 10.1067/moe.2000.107971

9. Wright JM, Vered M. Update from the 4th Edition of the World Health Organization classification of head and neck tumours: odontogenic and maxillofacial bone tumors. Head and Neck Pathol. 2017;11(1):68-77. doi: 10.1007/s12105-017-0794-1

10. Milman T, Ying GS, Pan W, LiVolsi V. Ameloblastoma: 25 year experience at a single institution. Head and Neck Pathol. 2016;10(4):513-20

11. Almeida RdeA, Andrade ES, Barbalho JC, Vajgel A, Vasconcelos $B C$. Recurrence rate following treatment for primary multicystic ameloblastoma: systematic review and meta-analysis. Int J Oral Maxillofac Surg. 2016;45(3):359-67. doi: 10.1016/j. ijom.2015.12.016

12. Anchlia S, Bahl S, Vyas S, Raju GS. Unicystic plexiform ameloblastoma with mural proliferation: a full-blown lesion BMJ Case Rep. 2016 Apr 6;2016. pii: bcr2015212778. doi $10.1136 / \mathrm{bcr}-2015-212778$

13. Sá ACD, Zardo M, Paes Junior AJO, de Souza RP, Neme MP Sabedotti I et al. Ameloblastoma da mandíbula: relato de dois casos. Radiol Bras. 2004;37(6):465-8. doi: 10.1590/S010039842004000600017

14. Silva AN, Stateri HQ. Tratamento cirúrgico do ameloblastoma sólido em adolescentes. Rev Bras Cir Craniomaxilofac. 2011;14(3):166-71

15. Young DR, Robinson M. Ameloblastomas in children. Report of a case. Oral Surg Oral Med Oral Pathol. 1962;15:1155-62. 
16. Saghravanian N, Salehinejas J, Ghazi N, Shirdel M, Razi M. A 40year retrospective clinicopathological study of ameloblastoma in Iran. Asian Pac J Cancer Prev. 2016;17(2):619-23.

17. Singh $M$, Shah $A$, Bhattacharya A, Raman $R$, Ranganatha $N$, Prakash P. Treatment Algorithm for Ameloblastoma. Case Rep Dent. 2014;121032:1-6. doi: 10.1155/2014/121032

18. Fregnani ER, Perez DEC, Almeida OP, Kowalski LP, Soares FA, Alves FA. Clinicopathological study and treatment outcomes of 121 cases of ameloblastomas. Int J Oral Maxillofac Surg. 2010;39(2):145-9. doi: 10.1016/j.ijom.2009.11.022

19. Valls A, Montané E, Bescós C, Saez M, Munill M, Alberola M. Manejo quirúrgico del ameloblastoma. Rev Esp Cir Oral Maxilofac. 2012;34(3):98-104. doi: 10.1016/j.maxilo.2012.02.001

20. Rezende ABM, Faber PA, Pino DS, Dias FJN. Tratamento Cirúrgico de Ameloblastoma Multicístico de Mandíbula. Rev Cient FHO|UNIARARAS. 2014;2(1):33-40.

21. Raldi FV, Guimarães-Filho R, Moraes MB, Neves ACC. Tratamento de ameloblastoma. RGO, Rev Gaúch Odontol. 2010;58(1):1236.
22. Kennedy WR, Werning JW, Kaye FJ, Mendenhall WM Treatment of ameloblastoma and ameloblastic carcinoma with radiotherapy. Eur Arch Otorhinolaryngol. 2016;273(10):3293-7. doi: 10.1007/s00405-016-3899-3

23. Lawal HS, Adebola RA, Arotiba JT, Amole IO, Efunkoya AA, Omeje UK et al. Quality of life of patients surgically treated for ameloblastoma. Niger Med J. 2016;57(2):91-8. doi: 10.4103/0300-1652.182069

24. Siar $\mathrm{CH}$, Lau SH. Ng KH. Ameloblastoma of the Jaws: A Retrospective Analysis of 340 Cases in a Malaysian Population. J Oral Maxillofac Surg. 2012 Mar;70(3):608-15. doi: 10.1016/j. joms.2011.02.039.

25. Hertog D, Bloemena E, Aartman IHA, Van-der-Waal I. Histopathology of ameloblastoma of the jaws; some critical observations based on a 40 years single institution experience. Med Oral Patol Oral Cir Bucal. 2012;17(1):e76-82. doi: 10.4317/ medoral.18006

Received on: 6/4/2017

Final version resubmitted on: 11/7/2017

Approved on:15/8/2017 